\title{
Effect of Phytohormones on rooting behaviour in air layers of Phoebe cooperiana, an economically important tree species of Arunachal Pradesh, India
}

\author{
Jasmine Pabin', N. Lyngdoh, T. S. Mehra3, M. Bishwapati Devi, Temin Payum5 \\ 'Department of Tree Improvement, College of Horticulture and Forestry, Central Agricultural University, Pasighat, \\ Arunachal Pradesh-791102, India, 'Biodiversity Research Centre, Mizoram University, Aizawl, Mizoram -796004, India, \\ ${ }^{3}$ Department of Forest Products Utilization, College of Horticulture and Forestry, Central Agricultural University, \\ Pasighat, Arunachal Pradesh-791102, India, ${ }^{4}$ Department of Basic Sciences, College of Horticulture and Forestry, \\ Central Agricultural University, Pasighat, Arunachal Pradesh-791102, India, ${ }^{5}$ Department of Botany, Jawaharlal Nehru \\ College, Pasighat, Arunachal Pradesh-791102, India
}

Received: June 25, 2021 Revised: August 30, 2021 Accepted: August 31, 2021 Published: October 13, 2021

*Corresponding Author: N. Lyngdoh

Email: lyngdoh@gmail.com

\begin{abstract}
This study reports the response of air layers of Phoebe cooperiana (Common name: Tapil) to different concentrations of rooting hormones in mid hills of Arunachal Pradesh. Ten trees between the ages of 7 and 10 were selected at Boleng village of Siang district, Arunachal Pradesh, India for the experiment. Eight treatments comprising of IBA and NAA at concentrations of 1000 ppm, 2000 ppm and 3000 ppm each, Rootex hormone for semi-hardwood and control were applied to a total of 240 layers during April 2020. After 60 days, rooting percentage, mean number of roots and length of the longest root were recorded. Significant variation $(\mathrm{p}<0.05)$ among treatments was observed for all root parameters. Among treatments, the highest rooting percentage and mean number of roots were obtained in layers treated with NAA $3000 \mathrm{pPm}(80 \%$ and 21.33 respectively). The length of the longest root was the highest in layers treated with NBA $2000 \mathrm{ppm}(4.23 \mathrm{~cm})$. The highest survival percentage of layers two months after transplanting was observed in those treated with NAA $3000 \mathrm{ppm}$ $(54.16 \%)$ and the least in control (23.07\%). The technique offers an easy and cheap method of propagation for farmers as well as for government and private agencies to enhance seedling production of the species.
\end{abstract}

KEYWORDS: Phoebe cooperiana, IBA, NAA, rooting, survival percentage, vegetative propagation

\section{INTRODUCTION}

Tapil (Phoebe cooperiana (U.N Kanjilal ex A.Das; Family Lauraceae) is an indigenous fruit tree (IFT) naturally distributed in several states of north-east India and in the South East Asian countries. It yields an economically important fruit consumed by tribal communities in the state of Arunachal Pradesh, India. The fruit is eaten at all developmental stages promoting early harvest of immature fruits during August and continues till maturity during October. Fruits are sold at prices ranging from $\$ 8$ to $\$ 9$ for 100 fruits, or privately owned trees are leased at $\$ 250-\$ 300$ for a single season to local traders and middle- men (Dolley et al., 2020). The species also possesses excellent timber quality (BII class timber) and has high demand in the entire region especially for furniture making (Payum et al., 2013). Consequently it has become one of the favorite IFT species of the local people which can provide quick intermittent returns within a short period as well as financial security in the future.

Scarcity of seed material and lack of knowledge on alternative propagation techniques impede plant multiplication of many IFTs. They are also seen as factors that inhibit farmers from cultivating these trees (Schreckenberg et al., 2002; Akinnifesi et al., 2008). Therefore, developing protocols of vegetative propagation is one of the core activities in a domestication program of IFTs (Raebild et al., 2011). It is also a viable alternative to meet seedling requirement for enriching agricultural landscapes and reviving natural populations. While there is considerable information on vegetative propagation of many IFT species of regional importance using stem cuttings (Tchoundjeu et al., 2006; Mng'omba et al., 2008; Antonia et al., 2014), grafting (Mkonda et al., 2001; Mng'omba et al., 2007; Parveen, 2016) and air layering (Mapongmetsem \& Diksia, 2014;

Copyright: (C) Pabin, et al. This article is open access and licensed under the terms of the Creative Commons Attribution License (http://creativecommons.org/licenses/by/4.0/) which permits unrestricted, use, distribution and reproduction in any medium, or format for any purpose, even commercially provided the work is properly cited. Attribution — You must give appropriate credit, provide a link to the license, and indicate if changes were made. 
Bhattacharjee et al., 2018; Kamila \& Panda, 2019), there is a lack of knowledge for many which are of local importance. In Arunachal Pradesh, planting materials of $P$. cooperiana are in high demand. However, due to the scarcity of seed and lack of alternative propagation methods, seedling production is limited and costly. The cost of a single seedling can be more than $\$ 1$, which becomes unaffordable for many marginal and small farmers. In light of the above, an investigation was undertaken to explore the amenability of different methods of vegetative propagation for the multiplication of the Tapil. Four methods of vegetative propagation including stem cuttings, budding, grafting and air layering were initially tried, out of which only air layering was successful and presented herewith.

\section{MATERIALS AND METHODS}

Air layering experiment of Tapil tree was carried out at Boleng village (28033' 60"N; 94096' 17"E; 390m above mean sea level), Siang district of Arunachal Pradesh, India, during April 2020. The climatic condition of the area is that of humid subtropical. The pre monsoon rain begins from month of March, and monsoon lasts up to October with the highest rainfall occurring during the month of June and July.

Ten mother trees between the ages of 7 to 10 in a single plantation were selected for air layering. Lower branches of the mother trees having a diameter of 2.0-2.5 cmwere chosen and a strip of the bark measuring 2-3 cm was removed from the selected branch. The exposed areas were then pasted with phytohormones at varying concentrations mixed with talc powder. The air layers were subjected to eight treatments which were Indole Butyric Acid (IBA) and Napthalene Acetic Acid (NAA) @ 1000 ppm, 2000 ppm and 3000 ppm each, commercial Rootex hormone for semi hardwood and control, which consisted only talc paste. The treated part was then covered with a ball of soil mixed with dried cow dung in a ratio of 1:1 (Das et al., 2015). Soil and dried cow dung was the choice of rooting media because they are locally available and cost effective. The rooting media was then covered with polythene tubing and both the ends were secured firmly using gunny thread. A total of 240 layers were prepared in Completely Randomized Design (CRD) with each treatment consisting of 30 layers in 3 replications distributed equally among the 10 trees.

The layers were separated from the mother plant after 60 days of operation when the outer surface of rooting medium within the wrapped polyethylene sheet was full of newly formed roots (Figure 1A). The layers were carefully detached from the mother tree and dipped in water to remove the media before root parameters were recorded (Figure 1B). The mean rooting percentage per treatment was calculated by counting number of rooted layers divided by total layers per treatment and expressed in percentage. The mean number of roots was estimated by counting all primary roots of rooted layers in each replication and averaging them. Length of the longest primary root was measured from collar region to the tip of longest primary root and mean value was calculated in centimeters $(\mathrm{cm})$. The detached layers were immediately planted in the prepared polybags of $20 \times 10 \times 7 \mathrm{~cm}$ filled with sand, soil and FYM in a ratio of 1:1:1 and kept under shade. Survival percentage was recorded two months after transplanting by counting number of seedlings that survived divided by total transplanted under each treatment (Figure 1C).

The data for different parameters were tabulated and statistically analyzed as per the methods outlined by Panse and Sukhatme (1967) followed by a post hoc LSD test at $\mathrm{p}<0.05$. Simple correlation coefficient was used to determine the degree of association among root parameters and survival percentageas per the formula given by Weber and Moorthy (1952).

\section{RESULTS}

We observed significant difference $(\mathrm{P}<0.05)$ in the response of air layers treated with different auxin concentrations for rooting percentage, mean root number and length of the longest root (Table 1). Between the auxins used, NAA treated layers responded better compared to IBA and the commercial rooting hormone 'Rootex' (Table 1). The rooting percentage was twice higher and the mean number of root almost four times more in NAA treated layers compared to IBA treated ones. The highest rooting percentage was obtained in layers treated with

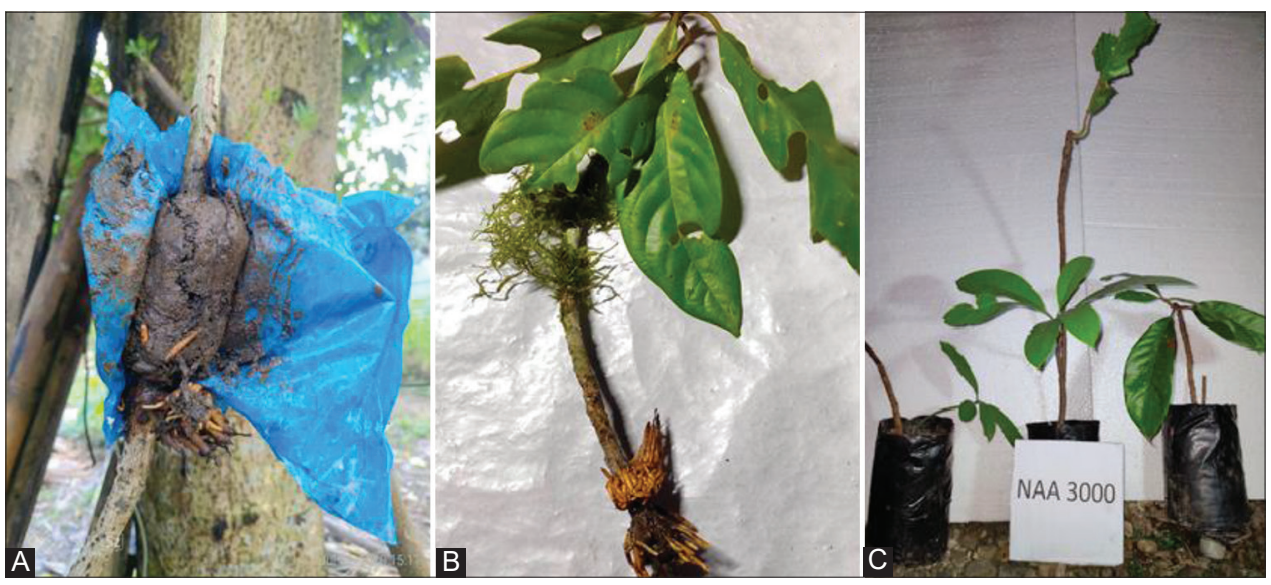

Figure 1: 'A'- Rooted layers of Phoebe cooperiana 60 days after layering; 'B'- Rooted layers of Phoebe cooperiana treated with NAA@ 3000 ppm 60 days after layering; ' $C$ '- Rooted seedling of Phoebe cooperiana treated with NAA@ 3000 ppm two months after transplanting 
Table 1: Rooting percentage, number of roots per layer and length of the longest root of layers of Phoebe cooperiana treated with different concentration of rooting hormones

\begin{tabular}{llccc}
\hline SI. No. & Treatments & $\begin{array}{c}\text { Rooting } \\
\text { percentage }\end{array}$ & $\begin{array}{c}\text { Number of } \\
\text { roots per layer longest root }(\mathrm{cm})\end{array}$ \\
\hline 1 & IBA1000 & $43.33(42.91)$ & 5.43 & 1.34 \\
2 & IBA2000 & $33.33(35.64)$ & 4.87 & 1.45 \\
3 & IBA3000 & $63.33(56.59)$ & 5.03 & 1.85 \\
4 & NAA1000 & $76.67(70.14)$ & 12.93 & 3.79 \\
5 & NAA2000 & $73.33(65.93)$ & 13.90 & 4.23 \\
6 & NAA3000 & $80.00(74.36)$ & 21.33 & 3.76 \\
7 & R0OTEX & $56.67(51.65)$ & 4.57 & 1.77 \\
8 & CONTR0L & $43.33(42.07)$ & 3.33 & 1.52 \\
& Mean & $58.75(54.91)$ & 8.93 & 2.46 \\
& C.V. (\%) & 16.29 & 41.32 & 51.74 \\
& F ratio & 7.6341 & 9.0714 & 13.162 \\
& S.Em & 5.1646 & 2.133 & 0.3396 \\
& C.D. @5\% & 13.875 & 5.719 & 1.018 \\
\hline
\end{tabular}

*Figures in parenthesis indicate arc sine transformed values

NAA $3000 \mathrm{ppm}(80 \%)$ and the lowest was with IBA $2000 \mathrm{ppm}$ (33.33\%). The rooting percentage of layers treated with NAA at $1000 \mathrm{ppm}, 2000 \mathrm{ppm}, 3000 \mathrm{ppm}$ and IBA at $3000 \mathrm{ppm}$ were significantly higher than the control (43.33\%). The highest mean number of roots was also obtained for layers treated with NAA 3000 ppm and the lowest was in control (Table 1). Length of longest root was seen to be highest in layers treated with NAA $2000 \mathrm{ppm}(6.62 \mathrm{~cm})$ and the lowest in IBA $1000 \mathrm{ppm}(1.43 \mathrm{~cm})$. Rooting percentage between layers treated with NAA 1000 ppm and NAA $3000 \mathrm{ppm}$ did not vary significantly; however, there was a large difference in the mean number of roots per layer (12.93 and 21.33, respectively).

The survival percentage of layers two months after transplanting ranged from $10.53 \%$ (IBA $3000 \mathrm{ppm}$ ) to $54.16 \%$ (NAA $3000 \mathrm{ppm}$ ). Higher survival percent was observed in layers treated with NAA as compared to IBA and 'Rootex' treated layers. The control had a survival percentage of $23.07 \%$ similar to layers treated with IBA $1000 \mathrm{ppm}$ (Figure 2). Positive correlations were obtained between all root parameters and survival percentage (rooting percentage $\mathrm{r}^{2}=0.47 ; \mathrm{p}<0.05$ at d.f $=6$; length of longest root $\mathrm{r}^{2}=0.66 ; \mathrm{p}<0.05$ at d.f $=6$ ); however, mean number of roots was the only parameter that was significant $\left(r^{2}=0.79 ; \mathrm{p}<0.05\right.$ at d.f $=6$; Figure 3).

\section{DISCUSSION}

Vegetative propagation offers multiple benefits in the domestication of IFTs where true-to-type plants can be propagated in large scale and fruit bearing period reduced drastically. As mentioned earlier, we failed to obtain successful grafts and budded plants in the species and met with limited success in inducing roots among stem cutting. Air layering has an advantage over other techniques of vegetative propagation because reserve food of the parent branch induces welldeveloped roots and the need of scion-stock compatibility does not arise. Therefore, it becomes a viable option for difficult to root species like Tapil and also practiced in Myrica esculenta (Bhatt, 2000) and Diospyros ebenum (Mewar \& Naithani, 2016).

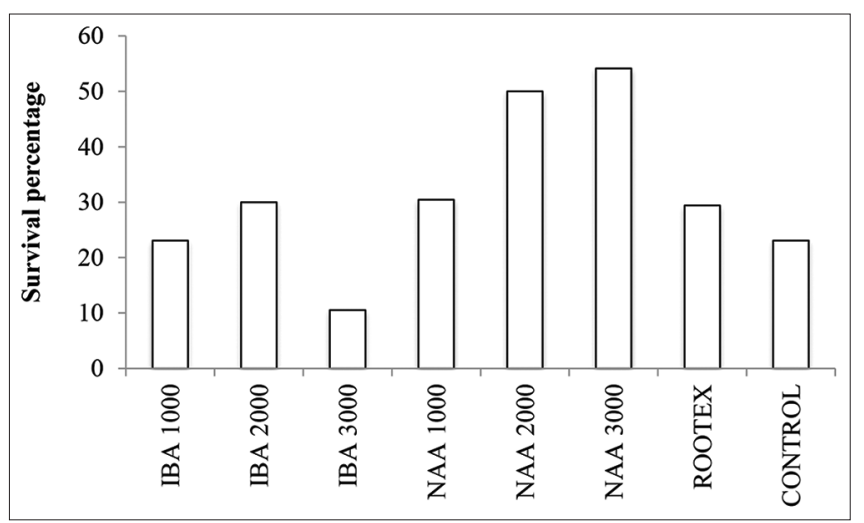

Figure 2: Survival percentage of layers of Phoebe cooperiana treated with different concentrations of hormones two months after transplanting

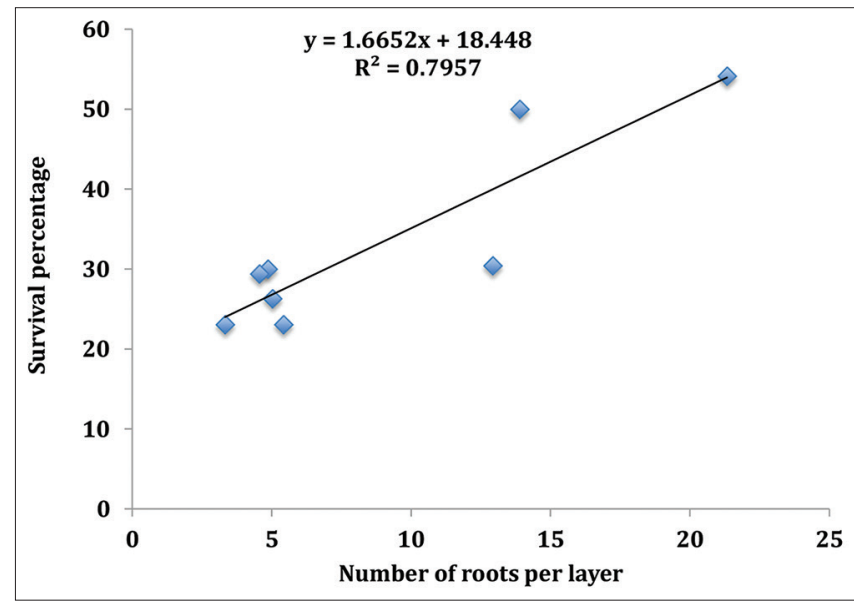

Figure 3: Correlation graph between number of roots and survival percentage of layers of Phoebe cooperiana two months after transplanting

Beside the contribution of endogenous auxins to root development (Overvoodre et al., 2010; Tiberia et al., 2011), many studies have shown that exogenous application of auxins results in increased initiation of lateral roots (Chhun et al., 2003). However plant species are known to differ in their response to the type and concentration of auxin that is externally applied. We observed better response of Tapil layers for rooting percentage, mean number of roots and length of longest root in NAA treated layers compared to IBA (Table 1). A similar response was observed in cuttings of Nyssa aquatica treated with NAA which produced up to eight times more roots than cuttings treated with no auxin or IBA (Boyer \& Graves, 2009). The application of NAA was also observed to significantly enhance rooting ability and root quality of layers compared to untreated or control layers, which becomes vital for generating more number of clonal material from selected genotypes.

Rooting percentage, mean root number and length of longest root were highest in layer treated with NAA $3000 \mathrm{ppm}$. The results are similar to that reported in air layering of litchi by Jan et al. (2003) wherein rooting percentage and number of roots per layer were highest in NAA@3000 ppm treated layers (74.36\% 
and $21.33 \mathrm{~cm}$, respectively) compared to other concentrations $(0,1000,1500,2000,2500$ and $3500 \mathrm{ppm})$. In our study, the maximum concentration of hormone used was $3000 \mathrm{ppm}$. Chatterjee (1982) successfully propagated by air-layering of mango using concentrations of 5000 and 10000 ppm of IBA and NAA. Hence, there is a possibility of obtaining higher rooting percentage and better rooting quality in Tapil under higher concentrations of rooting hormones.

Successful seedling establishment is largely dependent on the capacity of seedlings to rapidly initiate new roots (Grossnickle, 2005). Likewise, proper root development is essential for successful establishment of layers. In the present study, we observed significant positive correlation between survival percentage and mean number of roots (Figure 2) which clearly indicates that root quality is crucial for survival, especially after the layers are separated from the mother plant and transferred to new environments. Type of rooting hormone and concentration are known to influence survival of layers by directly affecting root parameters in litchi and mango as well (Rahman et al., 2000; Bhattaccharjee et al., 2018).

This study is the first report on successful multiplication of Phoebe cooperiana using vegetative tissue by air layering. Through this technique farmers can now propagate true-to-type trees of their choice to meet their own demand for planting materials. Additionally the method can also be exploited by institutions and agencies for establishing clonal banks for conserving wild gene pool of the species which is fast depleting in its natural habitat. Given that air layering as a method of multiplication is constrained by number of plantlets that can be generated from a single tree, the prospect of multiplication through stem cuttings should be revisited using other rooting hormones and over a wider range of concentration.

\section{ACKNOWLEDGEMENT}

The authors acknowledge the support received from the Central Agricultural University, Imphal under the project "Domestication of Phoebe cooperiana: An economically important wild edible fruit tree species of Arunachal Pradesh" (Grant No: CAU-DR/3-3(Horti.)/2010/Vol III/657 dtd 29 ${ }^{\text {th }}$ June 2017).

\section{REFERENCES}

Akinnifesi, F. K., Kwesiga, F. R., Mhango, J., Mkonda, A., Chilanga, T., \& Swai R. (2004). Domesticating priority fotmiombo indigenous fruit trees as a promising livelihood option for small-holder farmers in southern Africa. Acta Horticulture, 255, 546-557. https://doi. org/10.17660/ActaHortic.2004.632.1.

Anjarwalla, P., Ofori, D., Owino, A., Matuku, D., Adika, W., Njogu, K., \& Kehlenbeck, K. (2017). Testing different grafting methods for vegetative propagation of baobab (Adansonia digitata L.) in Kenya to assist its domestication and promote cultivation. Forests, Trees and Livelihoods, 26(2), 85-95. https://doi.org/10.1080/14728028.20 16.1202791

Bhattacharjee, P., Sakthinel, T., Naik, N., Gowda, I. N. D., Aswath, C., Nataraja, K. H., Awachara, C., \& Kumar, R. S. (2018). Effects of rooting media and different IBA concentrations on air layering of Rambutan (Nephelium lappaceum L.). International Journal of Chemical Studies, 6(4), 3300-3304
Bhatt, I. D. (2000). Studies on genetic variability and multiplication potentia of Myrica esculanta in Kumaun Himalaya. Ph. D. Thesis, H.N.B. Garhwal University Srinagar Garhawal, UA, India.

Boyer, N., \& Graves, W. (2009). NAA is more effective than IBA for rooting stem cuttings of two Nyssa spp. Journal of Environmental Horticulture, 27(3), 183-187. https://doi.org/10.24266/0738-289827.3.183.

Chhun, T., Taketa, S., Tsurumi, S., \& Ichii, M. (2003). The effects of auxin on lateral root initiation and root gravitropism in lateral rootless mutant Lrt1 of rice (Oryza sativa L.). Plant Growth Regulatin, 39(2), 161-170. https://doi.org/10.1023/A:1022592511387.

Das, A. C., Rahman, M. M., Rob, M. M., Mahmud, M. M. C., \& Sabur, S. A. (2015). Effects of time and rooting media on survivability of air layering in Guava. Bangladesh Journal of Progressive Science \& Technology, 13(1), 009-016.

Dolley, N., Lyngdoh, N., Singh, S., Singh, M. C., Devi, M. B., \& Hazarika, B. N. (2020). Domestication of Phoebe cooperiana in the Eastern Himalayas: population variation in morphological and biochemical fruit parameters. Plant Genetic Resources, 18, 259 - 269. https://doi. org/10.1017/S1479262120000210.

Akinnifesi, F. K., Leakey, R. R. B., Ajaui, O. C., Sileshi, G., Tchoundjeu, Z., Matakala, P., \& Kwesiga, F. R. (2008). Indigenous fruit trees in the tropics: domestication, utilization and commercialization. CABI, Oxfordshire. http://doi.org/10.1079/9781845931100.0000.

Grossnickle, S. C. (2005). Importance of root growth in overcoming planting stress. New Forests, 30, 273-294. https://doi.org/10.1007/ s11056-004-8303-2.

Hartmann, H. T., Kester, D. E., Davies, F. T., \& Geneve, R. L. (2002). Hartnann and Kester's plant propagation. Principles and practices. Seventh edition. Prentice Hall. Upper Saddle River, New Jersey.

Jan, N. E., Wazir, F. K., Mohammad, H., \& Ali, A. (2003). Effect of different concentration of IBA on rooting of Litchi in air layering. Sarhad Journal of Agriculture, 19(1), 47-54.

Love, K., Paull, R. E., Cho, A., \& Kawabata, A. (2017). Tropical Fruit Tree Propagation Guide. College of Tropical Agriculture and Human Resources. University of Hawai'i at Manoa.

Mapongmetsem, P. M., \& Diksia, M. (2014). Vegetative propagation of local fruit trees by air layering in the Guinean Savannah Highlands (GSH), Journal of Sustainable Forestry, 33, 1, 21-32. https://doi.org/10.108 0/10549811.2013.804420

Mckey, D., Elias, M., Pujol, B., \& Duputié. (2010). The evolutionary ecology of clonally propagated domesticated plants. New Phytologist, 186, 318-332. https://doi.org/10.1111/j.1469-8137.2010.03210.x.

Mewar, D., \& Naithani, D. C. (2016). Effect of different IBA concentrations and planting time on stem cuttings of wild Fig (Ficus palmata Forsk.). Plant Archives, 16(2), 959-962.

Mkonda, A., Akinnifesi, F. K., \& Mafongoya, P. (2001). Response of indigenous and exotic fruit trees in Zambia to grafting and air-layering. Proceeding of the 14 th Southern Africa Regional Review and Planning Workshop, 3-7 ${ }^{\text {th }}$ September, Harare, Zimbabwe: ICRAF, pp. 136- 139.

Mng'omba, S. A., Akinnifesi, F. K., Sileshi, G., Ajayi, O. C., Chakeredza, S. \& Mwase W. F. (2008). A decision support tool for propagating Miombo indigenous fruit trees of southern Africa. African Journal of Biotechnology, 7(25), 4677-4686. https://doi.org/10.4314/AJB. V7125.59656

Mng'omba, S. A., du Toit, E. S., Akinnifesi, F. K., \& Venter, H. M. (2007b). Histological evaluation of early graft compatibility in Uapaca kirkiana Muell Arg. scion/stock combinations. HortScience, 42,1-5. https:// doi.org/10.21273/HORTSCI.42.3.732.

Nyamukuru, A., Tabuti, J. R. S., \& Aduma, P. R. (2014). Propagation and seedling establishment of selected multipurpose woody species of Uganda, International Journal of Biodiversity Science, Ecosystem Services \& Management, 10, 4, 270-274. https://doi.org/10.1080/2 1513732.2014.953584.

Overvoorde, P., Fukaki, H., \& Beeckman, T. (2010). Auxin control of root development. Cold Spring Harbor Perspectives in Biology, 2(6), a001537. https://doi.org/10.1101/cshperspect.a001537.

Panse, V. G., \& Sukhatme, P. V. (1967). StatisticalMethods for Agricultural Workers. $2^{\text {nd }}$ Edition, ICAR publication, New Delhi. $381 \mathrm{p}$.

Pauku, R. L. (2005). Domestication of indigenous nuts for agroforestry in the Solomon Islands. Ph.D Thesis, James Cook University, Cairns, Queensland, Australia. Pp-381.

Payum, T., Das, A. K., Ramashankar, R., Tamuly, C., \& Hazarika, M. (2013). Ethnobotany and antioxidant determination of Phoebe cooperiana 
Pabin et al.

fruit- A highly utilized wild fruit in Arunachal Pradesh, India.

International Journal of Pharmaceutical Sciences and Research, 4(8). https://doi.org/10.13040/IJPSR.0975-8232.4(8).3196-01.

Ræbild, A., Larsen, A. S., Jensen, J. S., Ouedraogo, Z. M., De Groote, S., Van Damme, P., Bayala, J., Diallo, B. O., Sanou, H., Kalinganire, A., \& Kjaer, E. D. (2011). Advances in domestication of indigenous fruit trees in the West African Sahel. New Forests, 41(3), 297-315. https:// doi.org/10.1007/s11056-010-9237-5.

Rahman, N., Hussain, I., Imran, M., Jan, T., \& Awan, A. A. (2000). Effect of different concentrations of IBA on rooting of litchi (Litchi chinensis) in air layering. Pakistan Journal of Biological Sciences, 3(11), 1809-1810. https://doi.org/10.3923/pjbs.2000.330.331.

Simons, A. J. (1996). ICRAF's strategy for domestication on non-wood tree products. p. 822. In Domestication and commercialization of non-timber forest products in agroforestry systems. Proceedings of an international conference held in Nairobi, 19-23 February 1996. Non -wood Forest Products. 9. FAO: Rome.

Tchoundjeu, Z., Asaah, E. K., Anegbeh, P., Degrande, A., Mbile, P., Facheux, C., Tsobeng, A., Atangana, A. R., Ngo Mpeck, M. L., \& Simons, A. J. (2006). Putting participatory domestication into practice in West and Central Africa. Forests, Trees and Livelihoods, 16, 53-69. http://doi.org/10.1080/14728028.2006.9752545.

Tiberia, I. P., Pamfi, D. \& Bellini, C. (2011). Auxin control in the formation of adventitious roots. Notulae Botanicae Horti Agrobotanici ClujNapoca, 39(1), 307. http://doi.org/10.15835/nbha3916101.

Weber, C. R., \& Moorthy, B. R. (1952). Heritable and non-heritable relationships and variability of oil content and agronomic characters in the F2 generation of soybean crosses. Agron. Jounal, 44, 202-209. https://doi.org/10.2134/agronj1952.000219 $62004400040010 x$. 